\title{
Passionflower supplementation in diets of Japanese qualis at rearing and laying periods ${ }^{1}$
}

\author{
Janaina Della Torre da Silva ${ }^{2}$, Rodrigo Antonio Gravena ${ }^{3}$, Rafael Henrique Marques ${ }^{3}$, \\ Vanessa Karla Silva ${ }^{3}$, Fabricio Hirota Hada $^{3}$, Vera Maria Barbosa de Moraes ${ }^{4}$, Ramon Diniz \\ Malheiros $^{5}$
}

\footnotetext{
${ }^{1}$ Projeto financiado parcialmente pelo CNPq e pela FAPESP.

2 Doutor em Zootecnia pela FCAV-UNESP/Jaboticabal.

${ }^{3}$ Mestrando da FCAV-UNESP/Jaboticabal.

${ }^{4}$ Departamento de Zootecnia da FCAV-UNESP/Jaboticabal.

${ }^{5}$ Doutor em Ciência Animal pela FCAV-UNESP/Jaboticabal.
}

ABSTRACT - The objective of this study was to assess the effect of the inclusion of passionflower (Passiflora alata) in diets on performance, behavior, heterophil/lymphocyte ratio $(\mathrm{H} / \mathrm{L})$, corticosterone plasma levels (CPL) and immune response of quails. The study was carried out using 192 birds, distributed in randomized blocks with 4 diets $(0,125,250$ and 375 and 0, 250, 500 and $750 \mathrm{mg}$ of passionflower/kg of feed for the rearing and laying period, respectively), 8 replicates and 6 birds per experimental unit. The rearing period began when birds were 28 days of age and it lasted for 15 days. In this phase, it was evaluated daily feed intake, daily weight gain, feed conversion, viability, tonic immobility time, intensity of injuries, behavior, heterophil/lymphocyte ratio, and corticosterone plasma levels. Laying phase started when birds were 43 days of age and it finished when they were 140 days of age; it was compesed of six 14-day cycles in which it evaluated feed intake, feed conversion, egg production and quality, viability, tonic immobility time, intensity of injuries, behavior, heterophil/ lymphocyte ratio, corticosterone plasma levels and immune response. In the rearing period, the use of passionflower in the diet of quails influenced the behavioral parameters, and the birds became calmer, mainly at the dosage of $375 \mathrm{mg} / \mathrm{kg}$ of ration. However, in the laying period, passionflower was efficient in reducing stress in the quails, and the most promising results are observed when higher dosages of the phytotherapic were applied. Nevertheless, the dose of $750 \mathrm{mg} / \mathrm{kg}$ of feeeding reduces egg production, though it does not influence quality of eggs neither immune response of the quails.

Key Words: behavior, corticosterone, heterophil/lymphocyte ratio, immune response, stress, tonic immobility

\section{Efeitos da utilização de passiflora em rações de codornas japonesas nas fases de recria e postura}

RESUMO - Objetivou-se avaliar o efeito da inclusão de passiflora na ração sobre o desempenho, o comportamento, a relação heterófilo/linfócito, a concentração plasmática de corticosterona e a imunidade de codornas. Foram utilizadas 192 aves, distribuídas em blocos casualizados com 4 dietas (0, 125, 250 e 375, e 0, 250, 500 e $750 \mathrm{mg}$ de passiflora/kg de ração nas fases de recria e postura, respectivamente), 8 repetições e 6 aves por parcela. A fase de recria iniciou-se aos 28 dias de idade das aves e teve duração de 15 dias. Nesta fase foram avaliados o consumo diário de ração, o ganho diário de peso, a conversão alimentar, a viabilidade, o tempo em imobilidade tônica, a intensidade de ferimentos, o comportamento, a relação heterófilo/ linfócito e concentração plasmática de corticosterona. A fase de postura teve início quando as aves atingiram 43 dias de idade e seu término encerrou-se aos 140 dias de idade das aves; foi constituída de seis ciclos de 14 dias, nos quais foram avaliados o consumo de ração, a conversão alimentar, a produção e qualidade de ovos, a viabilidade, o tempo em imobilidade tônica, a intensidade de ferimentos, o comportamento, a relação herófilo/linfócito, a concentração plasmática de corticosterona e a resposta imunológica. Na fase de recria, o uso de passiflora na dieta de codornas influenciou os parâmetros comportamentais, tornando as aves mais calmas, principalmente na dosagem de $375 \mathrm{mg} / \mathrm{kg}$ de ração. Já na fase de postura, foi eficaz na redução do estresse das codornas, e os resultados mais promissores foram observados quando aplicadas as maiores dosagens do fitoterápico. A dosagem de $750 \mathrm{mg} / \mathrm{kg}$ de ração, no entanto, diminui a produção de ovos, embora não tenha influência na qualidade dos ovos nem a resposta imunológica das aves.

Palavras-chave: comportamento, corticosterona, estresse, imobilidade tônica, imunologia, relação heterófilo:linfócito 


\section{Introduction}

There are several productive advantages in raising quails, such as low feed intake, easy management and sexual precocity. Despite of these positive factors, they also present aggressive behavior causing injuries by pecking each other (Cheng, 2002). This behavior can be intensified by stress, affecting productivity and comfort of these birds (Duncan, 1981; Mills \& Faure, 1990).

Just like other birds, quails present a peculiar behavior when threatened, called tonic immobility, which can be manifested when birds are exposed to adverse situations, mainly those that cause fear or stress (Jones et al., 1988). Observing this behavior, the stress can be quantified by inducing tonic immobility and by counting the time they stay in this state.

Stress may also be measured by the observation of aggressive behavior, the intensity of injuries on the head and on body of animals, and also by physiological parameters, such as heterophil/lymphocyte ratio, plasma corticosterone level and immune response.

Plasma corticosterone level indicates an acute stress in birds, while the number of heterophil and lymphocyte are indicators of chronic stress and the most reliable measurement for stress of broiler chickens (Gross \& Siegel, 1983; Elrom, 2000).

During stress, the central nervous system is able to influence the immune system response through mediation over neurovegetative functions since both systems share receptors for cytokines, neurotransmitters, hormones and neuropeptides (Blalock, 1984; Silva et al., 2003).

Passionflower is a phytotherapic largely used by the popular medicine and it is usually prescribed as a sedative and an anxiolytic (Müller et al., 2005). Studies conducted with humans proved that passionflower can substitute benzodiazepines in treatments of schizophrenia, annoyance and anxiety, with the same results of commercial drugs (Schellenberg et al., 1993; Schulz et al., 1997). When tested in rats, it caused muscle relaxation and sedation, without altering electric activity of Central Nervous System (Dhawan et al., 2001).

Therefore, the objective of this study was to assess the effect of passionflower feed supplementation on quality of eggs, performance, behavior, heterophil/lymphocyte ratio, corticosterone plasma levels and immune response of Japanese quails during rearing and laying periods.

\section{Material and Methods}

The experiment was carried out in a conventional shed of quails.
It was raised seven hundred Japanese quails from 1 to 21 days of age in a floor covered by wood shavings. Starter feed for quails and water was supplied ad libitum. Birds were warmed by infra-red lamps and environmental temperature was regulated according to the age of the birds: 1 to 3 days, 37 to $38^{\circ} \mathrm{C}$; 4 to 15 days, $32^{\circ} \mathrm{C}$; and after 16 days, without heating.

At 22 days of age, quails were vaccinated against Newcastle disease (NewVac ${ }^{\circledR}$ B1 strain), by ocular via. They were weighted and transferred to laying cages, $32 \times 36 \times 16 \mathrm{~cm}\left(192 \mathrm{~cm}^{2}\right.$ area per bird), according to recommendations by Singh \& Narayan (2002), where they were kept during a week for acclimation.

The rearing period began when birds reached 28 days of age and lasted until 42 days of age. Initial weight varied from 90 to $120 \mathrm{~g}$ from 192 quails that were distributed in randomized blocks, submitted to 4 diets ( 0 - control; 125; 250; and 375 mg of Passiflora alata/kg of feed), with 8 replicates of 6 birds per experimental unit. This density per cage was applied because the birds were not beak trimmed. Forestalling eventual deaths and keeping a constant population density of the experiment, other 12 quails were equally distributed in two cages for each diet supplied with the same experimental feed.

Feed supplied in this period (from 28 to 42 days of age) contained $20 \%$ of crude protein, 2,800 kcal of ME $/ \mathrm{kg}$, $0.80 \%$ of calcium and $0.45 \%$ of available phosphorous, according to nutritional requirements for laying quails (Murakami et al., 1993). Feed differed only on the level of passionflower dry extract.

In order to evaluate the productive performance, quails and feed from each experimental unit were weighted at the beginning and at the end of the rearing period. Therefore, it was possible to verify feed intake, weight gain and feed conversion.

Tonic immobility time and intensity of injuries were assessed when birds were 35 and 42 days of age. Tonic immobility time assessment was proceeded by transferring all birds from the same cage to a box. Then, one quail at a time was abruptly turned in dorsal decubitus on a plane surface, and before releasing the quail, a slight pressure was applied over the animal for approximately three seconds. After this procedure, the time that the birds remained in immobility was measured by using a digital chronometer. The state of tonic immobility was considered only if the bird remained immovable for at least ten seconds (Heiblum et al., 1998). The intensity of injuries was measured by the presence or absence of injuries on different parts of the body (head and body) of each bird. 
Observations concerning aggressive behavior were assessed by the following: 1) intensity of injuries, along with tonic immobility in the morning period, 2) direct and continuous observation of social behavior of the birds from each experimental unit and registration of aggressive behavior (mounting or pecking) and non-aggressive behavior (idle, eating and drinking) observed at focal samplings that lasted 5 minutes for each cage, in the morning period, always at the same hour, and when birds were 32, 36 and 40 days of age (Savory et al., 1999).

When birds were 34 and 41 days of age, blood samples were taken from two birds per experimental unit randomly assigned, totaling 64 samples for each collection. Blood was taken by puncture of brachial vein of the wing in two syringes for each bird, one with heparin for corticosterone analysis and other with EDTA (minimum amount) for heterophil and lymphocyte counting.

Approximately $0.5 \mathrm{~mL}$ of blood/bird was centrifuged at 3,000 rpm for 10 minutes for obtaining plasma, which was separated, then stored in eppendorf and frozen at $-20^{\circ} \mathrm{C}$ for further measurement of corticosterone level through radio immune essay kit according to methodology described by Malheiros et al. (2003).

Counting of heterophil and lymphocyte was made using approximately $0.1 \mathrm{~mL}$ of blood/bird smeared on slides. The heterophil:lymphocyte ratio was performed according to procedure described by Campo \& Dávila (2002), therefore 100 leucocytes, including the granular (heterophil, eosinophil, and basophil) and non-granular ones (lymphocyte and monocyte) were counted from each slide.

The laying period was when birds were from 43 to 140 days of age. The supplied feeds were isoproteic and isoenergetic, containing $18 \%$ of crude protein, 2,800 kcal of ME/kg, $2.50 \%$ of calcium and $0.55 \%$ of available phosphorous, according to nutritional requirements proposed by Murakami et al. (1993). Feed differed only on the levels of passionflower dry extract, which were the following: 0 (control); 250; 500; and $750 \mathrm{mg}$ of Passiflora alata/kg.

When birds reached $5 \%$ of production, a light program was started with gradual increases of light time until 17 hours of light/day was established.

Production of eggs was daily registered from the beginning of the laying period. The first cycle of production and the performance evaluations began when birds reached $50 \%$ of the production. From that day on, a new cycle was established every 14 days until 6 cycles were completed, and therefore, the quails completed 140 days of age.

At the end of each cycle, the leftovers of feed from each replicate were weighed. Also, the eggs were evaluated concerning internal (Haug unit and pH) and external (weight of eggs, egg shell thickness, and egg shell percentage) quality parameters. Weight and quality of eggs were assessed on the last three days of each cycle, also for each replicate. Then, feed intake, feed conversion (feed intake/ dozen of eggs and feed intake/amount of eggs), production of eggs and mortality expressed as viability (100 - number of dead birds) could be evaluated.

The tonic immobility time (Heiblum et al., 1998) and the intensity of injuries (Savory et al., 1999) on the head and body were evaluated by the same procedures used in the rearing period and performed at the end of each production cycle, totaling six evaluations.

Assessment of corticosterone plasma level (Malheiros et al., 2003) and heterophil/lymphocyte ratio (Campo \& Dávila, 2002) were performed by collection of blood samples from two birds randomly assigned from each experimental unit of each treatment when birds were 48, 97 and 140 days of age, totaling 64 samples. The procedures remained as described in the rearing period.

Once more quails were vaccinated for Newcastle disease (NewVac ${ }^{\circledR}$ B1 strain) by ocular via at 100 days of age. Ten days after the second dosage of the vaccine, blood samples were collected from two birds per experimental unit in order to evaluate the immune response. This procedure was repeated every ten days until 4 collections with 64 samples were completed. Blood samples were centrifuged at 3,000 rpm for 10 minutes. Serum was separated, stored in eppendorf and frozen at $-20^{\circ} \mathrm{C}$ for further evaluation by the hemagglutination-inhibition reaction and the ELISA kit test (anti-chicken serum).

Hemagglutination-inhibition reaction was made to ensure serum titration, because the fat concentration was high and that could alter the results obtained by the ELISA kit test (anti-chicken serum).

Data was verified concerning the presence of outliers and the compliance to presumptions of normality for studentized range (Cramer-von-Mises test) and homogeneity of variances (Levene test). Data was submitted to analysis of variance by GLM procedure of SAS ${ }^{\circledR}$ software (SAS, 1995) and, in case of significant difference, means were compared by Tukey test, at $5 \%$ of probability, and analysis of regression. Data concerned to intensity of injuries and behavioral expression were evaluated by Chi-Squared test.

\section{Results and Discussion}

Levels of passionflower supplemented in feed in the rearing period did not influence the performance of the birds (Table 1). Similar results were observed by Marques et al. (2006), who also did not verify any effect of the 
supplementation with valerian (Valeriana officinalis $L$.) and chamomile (Matricaria chamomilla L.) respectively, on the performance of the birds.

During the rearing period, no mortality was observed in the experiment. Times of quail tonic immobility differed $(\mathrm{P}<0.01)$ among the levels of Passiflora alata in the feed (Table 2), and the quails fed diets without the phytotherapic presented higher time of tonic immobility when compared to those fed diets with passionflower. This parameter of stress evaluation presented a quadratic response according to the levels of passionflower in the feed. However, the heterophil/lymphocyte ratio and the corticosterone plasma concentration did not vary among the different levels of Passiflora alata.

In accordance to the data described in this study for tonic immobility time, Marques et al. (2010) verified that chamomile extract supplemented in feed was also able to decrease the quails stress during the rearing period, and the best result was obtained with the highest dosage of chamomile/kg of feed.

Values observed in this study for heterophil/ lymphocyte ratio and corticosterone plasma level confirmed the results described by Gravena et al. (2007) and Marques et al. (2007, 2010), who did not notice any effect of the inclusion of valerian and chamomile on feed, on physiological parameters to measure stress in quails.

Incidence of injuries on the head and on the body reduced as the levels of passionflower in feed increased
(Table 3). When aggressive behavior (Table 4) was evaluated by observing quails humping and pecking each other, the birds fed higher dosage of passionflower showed to be less aggressive, mainly when compared to the ones supplied with control diet (34.40 and 57.15\%, respectively). Moreover, birds fed $375 \mathrm{mg}$ of passionflower $/ \mathrm{kg}$ of feed remained in idle longer than the ones fed other diets (31.90 and $10.75 \%$, respectively). Therefore, passionflower had anxiolytic/sedative effect, decreasing the incidence of aggressive behavior that may cause some kind of injury to the birds.

The results obtained in this study were better than the ones found by Marques et al. (2010), who did not observe differences on aggressive behavior of quails fed diets with chamomile. There are no reports in literature about passionflower effects on quails behavior, tonic immobility time and intensity of injuries.

The dosage of passionflower in the laying period was doubled in the rearing period because of the higher weights of the quails. However, there were no significant differences ( $\mathrm{P}>0.05$ ) of daily intake, feed conversion (intake/kg of eggs) and mortality rate (Table 5) among birds fed different diets. The best results for feed conversion $(\mathrm{kg} / \mathrm{dz}$ ) were obtained with feed containing $250 \mathrm{mg}$ of passionflower $/ \mathrm{kg}$, followed by 500 and $750 \mathrm{mg}$ of passionflower/kg. However, the results found with the higher dosages of passionflower did not differ statistically from the control feed either, indicating a quadratic response of feed conversion $(\mathrm{kg} / \mathrm{dz})$.

Table 1 - Performance of quails fed diets with Passiflora alata in the rearing period

\begin{tabular}{cccc}
\hline Passiflora alata $(\mathrm{mg} / \mathrm{kg})$ & Feed intake (g/day) & Weight gain (g/day) & Feed conversion \\
\hline 0 & 14.87 & 2.50 & 6.49 \\
125 & 14.92 & 2.35 & 6.83 \\
250 & 15.92 & 2.66 & 6.43 \\
375 & 15.06 & 2.47 & 6.55 \\
P value & 0.4450 & 0.2180 & 0.4764 \\
CV (\%) & 9.49 & 11.73 & 8.24 \\
\hline
\end{tabular}

$\mathrm{CV}=$ coefficient of variation.

Table 2 - Tonic immobility time, heterophil/lymphocyte ratio and corticosterone plasma level of quails fed diets containing Passiflora alata, in the rearing period

\begin{tabular}{cccc}
\hline Passiflora alata $(\mathrm{mg} / \mathrm{kg})$ & Tonic immobility time (seconds) & Heterophil/Lymphocyte ratio $^{\text {Corticosterone }}$ plasma level (ng/mL) \\
\hline 0 & $58.92 \mathrm{~b}$ & 0.497 & 197.48 \\
125 & $25.34 \mathrm{a}$ & 0.472 & 143.96 \\
250 & $23.10 \mathrm{a}$ & 0.463 & 105.23 \\
375 & $17.05 \mathrm{a}$ & 0.466 & 102.43 \\
P value & $<0.0001$ & 0.7668 & 0.0783 \\
CV (\%) & 38.38 & 15.02 & 56.60 \\
\hline
\end{tabular}

Means followed by the same letter in the same column do not differ by Tukey test.

$\mathrm{CV}=$ coefficient of variation.

${ }^{1} \mathrm{Y}=57.169-0.2675 \mathrm{x}+0.0004 \mathrm{x}^{2}\left(\mathrm{R}^{2}=0.1696\right)$. 
Table 3 - Intensity of injuries at head and body of quails fed diets with Passiflora alata, in the rearing period

\begin{tabular}{|c|c|c|c|c|}
\hline \multirow[t]{2}{*}{ Intensity } & \multicolumn{4}{|c|}{ Passiflora alata $(\mathrm{mg} / \mathrm{kg})$} \\
\hline & 0 & 125 & 250 & 375 \\
\hline & \multicolumn{4}{|c|}{ Head (\%) } \\
\hline Without injury & $45.84 c$ & $59.38 b$ & $61.05 \mathrm{~b}$ & $76.06 \mathrm{a}$ \\
\hline With injury & $54.16 \mathrm{c}$ & $40.62 b$ & $38.95 b$ & $23.96 a$ \\
\hline Chi-squared value & 45.82 & & & \\
\hline \multirow[t]{2}{*}{$P$ value } & \multicolumn{4}{|c|}{$<0.0001$} \\
\hline & \multicolumn{4}{|c|}{ Body (\%) } \\
\hline Without injury & $68.75 c$ & $69.79 c$ & $86.46 \mathrm{~b}$ & $91.66 a$ \\
\hline With injury & $31.25 c$ & $30.21 \mathrm{c}$ & $13.54 \mathrm{~b}$ & $8.34 \mathrm{a}$ \\
\hline Chi-squared value & \multicolumn{4}{|c|}{60.07} \\
\hline $\mathrm{P}$ value & \multicolumn{4}{|c|}{$<0.0001$} \\
\hline
\end{tabular}

Means followed by the same letter in the same line do not differ by Chi-squared test.

Table 4 - Distribution in percentage of the time spent on different behaviors of quails fed diets containing Passiflora alata, in the rearing period

\begin{tabular}{lcccc}
\hline Behavior & \multicolumn{4}{c}{ Passiflora alata $(\mathrm{mg} / \mathrm{kg})$} \\
\cline { 2 - 5 } & 0 & 125 & 250 & 375 \\
\hline Aggressive & $57.15 \mathrm{c}$ & $54.80 \mathrm{c}$ & $49.30 \mathrm{bc}$ & $34.40 \mathrm{a}$ \\
Idle & $10.75 \mathrm{c}$ & $11.80 \mathrm{c}$ & $17.20 \mathrm{~b}$ & $31.90 \mathrm{a}$ \\
Eating & 25.30 & 26.60 & 26.00 & 26.20 \\
Drinking & 6.80 & 7.20 & 7.50 & 7.50 \\
Chi-squared value & \multicolumn{5}{c}{54.19} \\
P value & $<0.0001$ \\
Means followed by the same letter in the same line do not differ by Chi-squared
\end{tabular}
test.

Egg production was also influenced by diets, because the best values were observed on birds fed control diets and $250 \mathrm{mg}$ of passionflower $/ \mathrm{kg}$ of feed. When results were submitted to regression analysis, a linear decrease of the production of eggs could be noticed as the dosages of passionflower in feed increased.

Results of feed intake, feed conversion (intake/ $\mathrm{kg}$ of eggs) and viability were in agreement with Rizzo et al. (2008), who did not observe any significant differences of these parameters in quails fed diets with increasing dosages of tryptophan, an essential amino-acid precursor for the neurotransmitter serotonin. Neither did Guarini et al. (2007) observe effect on the performance of quails fed diets supplemented with kava-kava (Piper methysticum) dry extract, a phytotherapic with anxiolytic/sedative function.

According to Ballone (2008), most of antidepressants and antianxyety medicines cause an increase of serotonin availability in the synaptic cleft along with a decrease of sexual hormones level, which would probably reduce the production of eggs, an undesirable effect for laying quails. This hypothesis may justify the drop on the production of eggs when the levels of passionflower in feed increased.

The inclusion of passionflower in diet did not interfere in the weight of eggs, shell thickness and percentage, Haugh unit and pH of eggs (Table 6). Similarly, Guarini et al. (2007) did not observe influence of the kava-kava supplementation on quail egg quality. Similar results were also reported by Hada et al. (2007), who evaluated egg quality from quails fed diets containing passionflower during 12 months and they did not observe any alteration in internal and external quality of eggs.

A significant effect of passionflower on tonic immobility time and corticosterone plasma level was observed in quails fed experimental diets, but, there were no difference in the heterophil/lymphocyte ratio (Table 7).

Birds fed diets with 500 and 750 mg of passionflower/ $\mathrm{kg}$ of feed presented less time of tonic immobility, indicating a reduction of stress caused by passionflower. A similar result was verified in a study with commercial product containing prebiotic, probiotic and phytotherapics in diets of laying quails, in which birds that received higher dosages of the product remained less time in tonic immobility when compared to those that did not received the product (Matos et al., 2007). Maybe this outcome resulted from the higher production of serotonin in the intestine, once the use of prebiotics and probiotics enhance the intestinal integrity. As a counterpart, Gravena et al. (2009) did not verify any effects of the valerian supplementation on tonic immobility time of laying quails, proving that the used dosage of these phytotherapics did not reduce stress.

Table 5 - Performance of laying quails, as a function of the inclusion of Passiflora alata in feed

\begin{tabular}{|c|c|c|c|c|c|}
\hline Passiflora alata $(\mathrm{mg} / \mathrm{kg})$ & Feed intake (g/dia) & Feed conversion $(\mathrm{kg} / \mathrm{dz})^{1}$ & Feed conversion $(\mathrm{kg} / \mathrm{kg})$ & Egg production ${ }^{2}(\%)$ & Viability (\%) \\
\hline 0 & 24.92 & $0.37 \mathrm{~b}$ & 2.57 & $86.59 a$ & 99.83 \\
\hline 250 & 24.38 & $0.34 \mathrm{a}$ & 2.45 & $85.24 a$ & 97.92 \\
\hline 500 & 23.76 & $0.35 \mathrm{ab}$ & 2.50 & 82.92ab & 99.91 \\
\hline 750 & 23.79 & $0.35 a b$ & 2.48 & $80.36 \mathrm{~b}$ & 99.81 \\
\hline Valor de $\mathrm{P}$ & 0.2284 & 0.0331 & 0.1672 & 0.0082 & 0.4505 \\
\hline CV (\%) & 5.14 & 3.91 & 3.88 & 4.09 & 2.88 \\
\hline
\end{tabular}

Means followed by the same letter in the same column do not differ $(\mathrm{P}>0.05)$ by Tukey's test.

$\mathrm{CV}=$ coefficient of variation.

${ }^{1} \mathrm{Y}=0.365-0.00008 \mathrm{x}+0.00000009 \mathrm{x}^{2}\left(\mathrm{R}^{2}=0.1688\right)$

${ }^{2} \mathrm{Y}=86.932-0.0084 x\left(\mathrm{R}^{2}=0.2892\right)$ 
Table 6 - External and internal quality of eggs from laying quails fed diets containing Passiflora alata

\begin{tabular}{cccccc}
\hline Passiflora alata $(\mathrm{mg})$ & Eggs weight $(\mathrm{g})$ & Shell thickness $(\mathrm{mm})$ & \% Shell & HaughUnit & $\mathrm{pH}$ \\
\hline 0 & 10.86 & 0.29 & 7.82 & 89.99 & 7.36 \\
250 & 10.80 & 0.30 & 7.89 & 90.02 & 7.32 \\
500 & 11.05 & 0.29 & 7.73 & 90.02 & 7.42 \\
750 & 10.95 & 0.29 & 0.73 & 90.28 & 0.9034 \\
P value & 0.8505 & 0.4382 & 2.45 & 1.16 & 0.3043 \\
CV (\%) & 2.84 & 3.62 & & & 1.93 \\
\hline
\end{tabular}

$\mathrm{CV}=$ coefficient of variation.

The inclusion of passionflower in feed decreased the levels of plasma corticosterone of laying quails, and the lowest levels were verified in plasma from birds fed diets containing $750 \mathrm{mg}$ of phytotherapic/kg of feed. However, Gravena et al. (2009) and Marques et al. (2007) did not verify any differences in heterophil/lymphocyte ratio or in corticosterone plasma level when quails were fed diets with valerian and chamomile. But according to Gross \& Siegel (1983), when stress lasted for long periods in broiler chickens, no significant alterations in the heterophil/lymphocyte ratio was verified, nevertheless, an atrophy of the primary lymphoid organs did occur.

Wolfman et al. (1994), Soulimani et al. (1997) and Dhawan et al. (2001) administered dry extract and fluid extract from shoot parts of passionflower through oral and intraperitoneal via in rats and they verified muscle relaxation and more time of sleep, proving the anxiolytic and sedative effect of the phytotherapic on physical parameters, without altering the physiological parameters, despite the evidence of the passionflower action as a natural calmative agent.

Injuries on the head and on the body of quails decreased with the inclusion of passionflower in diets (Table 8), and the injuries were inversely proportional to the levels of the phytotherapic in the diet. Different results were found by Gravena et al. (2009) and Silva et al. (2009), who did not observe any differences on the intensity of injuries of laying quails fed diets supplemented with valerian and kava-kava, respectively.
The behavior of quails during the laying period (Table 9) was similar to the rearing period. The birds were less aggressive as the passionflower level in feed increased. However, the supplementation of valerian in feed did not influence the behavior of quails, therefore the phytotherapic was considered inefficient, when studied isolated, to reduce aggressive behavior (Gravena et al., 2009).

In this study, there was no effect of the experimental diets on humoral immune response of the quails (Table 10), the values obtained by hemagglutination-inhibition (HI) test in birds vaccinated with $\mathrm{NewVac}{ }^{\circledR} \mathrm{B} 1$ strain was not satisfactory for quails immunization against Newcastle disease, although these birds had presented some resistance to the disease. Similar results were observed by Lima et al. (2004) in a research to assess immune parameters of quails, with four vaccine types and five vaccinations (one per week, against Newcastle disease). However, this author found high immune titles when serum was analyzed by ELISA test (conjugated serum).

Maybe the results found in this research with ELISA test are not in accordance to those found by Lima et al. (2004) due to the number of times that the birds were exposed to the virus and the immune analysis used, once, in this study, a commercial ELISA test (anti-chicken serum), while Lima et al. (2004) used a laboratory ELISA test made from laboratory animals serum (anti-rabbit anti-chicken conjugated serum).

The lack of works on the importance of anxiolytic and/or sedative usages on immune system does not allow

Table 7 - Tonic immobility time, heterophil/lymphocyte ratio and corticosterone plasma level of laying quails fed diets containing Passiflora alata

\begin{tabular}{cccc}
\hline Passiflora alata $(\mathrm{mg})$ & Tonic immobility time (seconds) & Heterophil/lymphocyte ratio $^{\text {Corticosterone }}$ plasma level (ng/mL) \\
\hline 0 & $32.35 \mathrm{c}$ & 0.475 \\
250 & $24.46 \mathrm{~b}$ & 0.452 & $280.32 \mathrm{~b}$ \\
500 & $9.21 \mathrm{a}$ & 0.437 & $179.82 \mathrm{~b}$ \\
750 & $3.08 \mathrm{a}$ & 0.455 & $169.00 \mathrm{~b}$ \\
P value & $<0.0001$ & 0.4345 & $142.84 \mathrm{a}$ \\
CV $(\%)$ & 31.43 & 9.55 & 24.56 \\
\hline
\end{tabular}

Means followed by the same letter in the same column do not differ by Tukey test.

${ }^{1} \mathrm{Y}=32.738-0.0412 \mathrm{x}\left(\mathrm{R}^{2}=0.2491\right)$.

${ }^{2} \mathrm{Y}=275.07-0.3923 \mathrm{x}+0.0003 \mathrm{x}^{2}\left(\mathrm{R}^{2}=0.5761\right)$. 
Table 8 - Means followed by the same letter in the same line do not differ by Chi-squared test. Intensity of injuries at head and body of laying quails fed diets containing Passiflora alata

\begin{tabular}{lccc}
\hline Intensity & \multicolumn{4}{c}{ Passiflora alata $(\mathrm{mg} / \mathrm{kg})$} \\
\cline { 2 - 5 } & 0 & 125 & 250 \\
\hline
\end{tabular}

Means followed by the same letter in the same line do not differ by Chi-squared test.

Table 9 - Behavior of laying quails fed diets containing Passiflora alata

\begin{tabular}{lcccc}
\hline Behavior & \multicolumn{4}{c}{ Passiflora alata $(\mathrm{mg})$} \\
\cline { 2 - 5 } & 0 & 250 & 500 & 750 \\
\hline Aggressive & $59.80 \mathrm{c}$ & $52.20 \mathrm{c}$ & $49.50 \mathrm{bc}$ & $30.70 \mathrm{a}$ \\
Idle & $6.80 \mathrm{c}$ & $12.00 \mathrm{~b}$ & $15.20 \mathrm{~b}$ & $33.90 \mathrm{a}$ \\
Eating & 26.00 & 26.10 & 26.40 & 25.80 \\
Drinking & 7.40 & 9.70 & 8.90 & 9.60 \\
Chi-squared value & \multicolumn{5}{c}{82.63} \\
P value & $<0.0001$ \\
\hline
\end{tabular}

Means followed by the same letter in the same line do not differ by Chi-squared test.

Table 10 - Serum antibody titers against Newcastle disease of laying quails fed diets containing Passiflora alata

\begin{tabular}{ccc}
\hline Passiflora alata (mg) & Hemagglutination-inhibition & ELISA \\
\hline 0 & 1.279 & 0.999 \\
250 & 1.597 & 1.096 \\
500 & 1.575 & 0.957 \\
750 & 1.329 & 0.903 \\
P value & 0.1794 & 0.1621 \\
CV (\%) & 19.08 & 17.07 \\
\hline
\end{tabular}

$\mathrm{CV}=$ coefficient of variation.

further discussion about this parameter in the present study. Therefore, more researches to verify the calmative effects on humoral immune response must be accomplished.

\section{Conclusions}

The use of passionflower in diet enhances the behavioral parameters of quails in the rearing period, because birds become calm, mainly with the dosage of $375 \mathrm{mg} / \mathrm{kg}$ of feed. In the laying period, however, promising results are obtained with $500 \mathrm{mg} / \mathrm{kg}$ of feed, because this dosage is enough for calmative effects without affecting production and quality of eggs or the immune response of the quails.

\section{Acknowledgements}

Thanks to Coordenação de Aperfeiçoamento de Pessoal de Nível Superior (CAPES), for granting the Master Degree scholarship, to Fundação de Amparo à Pesquisa do Estado de São Paulo (FAPESP) and to Conselho Nacional de Desenvolvimento Científico e Tecnológico (CNPq), for the research project grants, to Prof. Dr. Alice Eiko Murakami from Universidade Estadual do Maringá, for donating the experimental quails.

\section{References}

BALLONE, G.J. Serotonina. Disponível em: <http:// www.virtualpsy.locaweb.com.br>. Acesso em: 28/9/2008.

BLALOCK, J.E. The immune system as a sensory organ. Journal Immunology, v.132, n.3, p.1067-1070, 1984.

CAMPO, J.L.; DÁVILA, S.G. Effect of photoperiod on heterophil to lymphocyte ratio and tonic immobility duration of chickens. Poultry Science, v.81, n.11, p.1637-1639, 2002.

CHENG, K.M. Reprodução de codornas: onde estamos indo? In: SIMPÓSIO INTERNACIONAL DE COTURNICULTURA, 1. 2002, Lavras. Anais... Lavras: NECTA/UFLA, 2002. (CD-ROM).

DHAWAN, K.; KUMAR, S.; SHARMA, A. Anti-anxiety studies on extratcs of Passiflora incarnata Linneaus. Journal of Ethnopharmacology, v.78, n.2-3, p.165-170, 2001.

DUNCAN, I.J.H. Animal behavior and welfare. In: CLARK, J.A. (Ed.) Environmental aspects of housing for animal production. London: Butterworths, 1981. p.445-470.

ELROM, K. Review: handling and transportation of broilers welfare, stress, fear and meat quality. Journal of Veterinary Medicine, v.56, n.1, p.39-45, 2000.

GRAVENA, R.A.; MARQUES, R.H.; SILVA, J.D.T. et al. Níveis plasmáticos de corticosterona de codornas nas fases de recria e postura alimentadas com dietas contendo valeriana. Revista Brasileira de Ciência Avícola, supl.9, p.35, 2007.

GRAVENA, R.A.; MARQUES, R.H.; SILVA, J.D.T. et al. Uso da Valeriana offi cinalis em dietas de codornas japonesas na fase de postura. Biotemas, v.22, n.4, p.185-191, 2009.

GUARINI, A.R.; GRAVENA, R.A.; SILVA, J.D.T. et al. Efeito do kava-kava sobre o desempenho e qualidade de ovos de codornas. In: REUNIÃO ANUAL DA SOCIEDADE BRASILEIRA DE ZOOTECNIA, 44., 2007, Jaboticabal. Anais... Jaboticabal: SBZ, 2007. (CD-ROM).

GROSS, W.B.; SIEGEL, H.S. Evaluation of the heterophil/ lymphocyte ratio as a measure of stress in chickens. Avian Disease, v.27, n.4, p.972-979, 1983.

HADA, F.H.; MATOS, A.S.; SILVA, J.D.T. et al. Efeito de diferentes níveis de Passiflora alata sobre o desempenho e qualidade de ovos de codornas. In: REUNIÃO ANUAL DA SOCIEDADE BRASILEIRA DE ZOOTECNIA, 44., 2007, Jaboticabal. Anais... Jaboticabal: SBZ, 2007. (CD-ROM).

HEIBLUM, R.; AIZENSTEIN, O.; GVARYAHU, G. et al. Tonic immobility and open field responses in domestic fowl chicks during the first week of life. Applied Animal Behaviour Science, v.60, p.347-357, 1998. 
JONES, R.B.; BEUVING, J.; BLOKHUIS, H.J. Tonic immobility and heterophil/lymphocyte responses of the domestic fowl to corticosterone infusion. Physiology and Behavior, v.42, n.3, p.249-253, 1988.

LIMA, F.S.; SANTIN, E.; PAULILLO, A.C. et al. Japanese quail (Coturnix coturnix japonica) as Newcastle disease virus carrier. International Journal of Poultry Science, v.3, n.7, p.483-484, 2004.

MALHEIROS, R.D.; MORAES, V.M.B.; COLLIN, A. et al. Free diet selection by broilers as influenced by dietary macronutrients ratio and corticosterone supplementation. 1. Diet selection, organ weights, and plasma metabolites. Poultry Science, v.82, n.1, p.123-131, 2003

MARQUES, R.H.; GRAVENA, R.A.; SILVA, J.D.T. et al. Desempenho produtivo de codornas japonesas alimentadas com diferentes níveis de camomila. Revista Brasileira de Ciência Avícola, supl.8, p.64, 2006.

MARQUES, R.H.; GRAVENA, R.A.; SILVA, J.D.T. et al. Avaliação da concentração de corticosterona plasmática em codornas japonesas alimentadas com diferentes níveis de camomila. Revista Brasileira de Ciência Avícola, supl.9, p.34, 2007.

MARQUES, R.H.; GRAVENA, R.A.; SILVA, J.D.T. et al. Inclusão da camomila no desempenho, comportamento e estresse em codornas durante a fase de recria. Ciência Rural, v.40, n.2, p.415-420, 2010.

MATOS, A.S.; SILVA, J.D.T.; MARQUES, R.H. et al. Uso do Estibion Básico Plus ${ }^{\circledR}$ sobre o desempenho e estresse em codornas. Revista Brasileira de Ciência Avícola, supl.9, p.55, 2007.

MILLS, A.D.; FAURE, J.M. Panic and hysteria in domestic fowl: a review. In: ZAYAN, R.; DANTZER, R. (Eds.) Social stress in domestic animals. Dordrecht: Kluwer Academic Publisher, 1990. p.248-272.

MÜLLER, S.D.; VASCONCELOS, S.B.; COELHO, M. et al. LC and UV determination of flavonoids from Passiflora alata medicinal extracts and leaves. Journal of Pharmaceutical and Biomedicinal Analisys, v.37, n.2, p.399-403, 2005.

MURAKAMI, A.E.; MORAES, V.M.B.; ARIKI, J. Níveis de proteína e energia em dietas de codornas japonesas (Coturnix coturnix japonica) em postura. Revista Brasileira de Zootecnia, v.22, n.4, p.541-551, 1993.
RIZZO, P.V.; GUANDOLINI, G.C.; AMOROSO, L. et al. Triptofano na alimentação de codornas japonesas nas fases de recria e postura. Revista Brasileira de Zootecnia, v.37, n.6, p.10171022, 2008.

SAVORY, C.J.; MANN, J.S.; MACLEOD, M.G. Incidence of pecking damage in growing bantams in relation to food form, group size, stocking density, dietary tryptophan concentration and dietary protein source. British Poultry Science, v.40, n.5, p.579-584, 1999.

SCHELLENBERG, V.; SCHELLENBERG, R.; JAHNIG, L. Quantitative EEG monitoring in phyto and psychopharmacological treatment of psychosomatic and affective disorders. Schizophrenia Research, v.9, p.249-250, 1993.

SCHULZ, V.; BRUNING, J.; HUBNER, W.D. et al. Clinical trials with psycho-phytopharmaceuticals. Phytomedicine, v.3, p.8, 1997.

SINGH, R.V.; NARAYAN, R. Produção de codornas nos trópicos. In: SIMPÓSIO INTERNACIONAL DE COTURNICULTURA, 1., 2002, Lavras. Anais... Lavras, 2002. p.27-35.

SILVA, F.R.; LAZZARINI, R.; SÁ-ROCHA, L.C. et al. Effects of acute and long-term diazepam administrations on neutrophil activity: a flow cytometric study. European Journal of Pharmacology, v.478, n.2-3, p.97-104, 2003.

SILVA, J.D.T.; GUARINI, A.R.; SEKI-DIAS, L.T. et al. Avaliação do estresse em codornas alimentadas com kava-kava. In: REUNIÃO ANUAL DA SOCIEDADE BRASILEIRA DE ZOOTECniA, 46., 2009, Maringá. Anais... Maringá: SBZ, 2009. (CD-ROM).

SOULIMANI, R.; YOUNOS, C.; JARMOUNI, S. et al. Behavioral effects of Passiflora incarnata L. and its indole alkaloid and flavonoid derivates and maltol in the mouse. Journal of Ethnopharmacology, v.57, p.11-20, 1997.

STATISTICAL ANALYSIS SYSTEMS - SAS. SAS ${ }^{\circledR} /$ STAT User's guide. Version 6, 4.ed. Cary: SAS Institute Incorporation, 1995. $365 p$.

WOLFMAN, C.; VIOLA, H.; PALADI, A. et al. Possible anxiolytic effects of chrysin, a central benzodiazepine receptor ligand from Passiflora coerulea. Pharmacology Biochemistry Behavior, v.47, p.1-4, 1994. 